Iranian Quarterly Journal of Breast Disease 2018; 11(3):71.

\title{
Improvement of Genetic Bee Algorithm to Select the Effective Features in Predicting Breast Cancer from Among Dietary Habits, Cultural Factors, Clinical Signs, and Laboratory Results
}

\author{
Nooshyar M: Department of Computer, University of Mohaghegh Ardabili, Ardebil, Iran \\ Momeni M: Ph.D. Student, Computer Department, Yazd University, Yazd, Iran \\ Gharravi S: Electrical and Computer Department, Esfarayne Higher Education Complex, Northern Khorasan, \\ Esfarayne, Iran
}

Corresponding Author: Mehdi Nooshyar, nooshyar@uma.ac.ir

\begin{abstract}
Introduction: The identification of factors influencing the incidence of breast cancer bears great importance. The wide range of symptoms of the disease makes the diagnosis difficult for doctors. Preventing breast cancer could be achieved via a knowledge of the factors affecting the incidence of the disease. The purpose of this paper was to identify variables related to dietary habits, cultural factors, and laboratory results that could contribute to the effective prediction of breast cancer. For this purpose, an optimal model based on genetic bee colony (GBC) algorithm was developed to increase machine learning accuracy.
\end{abstract}

Methods: In this study, patient information was collected from the database of Mortaaz subspecialty hospital in Yazd. Medical records of 711 breast cancer patients were screened for 63 variables. Patients had been followed up for at least two years. Variables most affecting the incidence of breast cancer were identified using the GBC algorithm and backup vector machine.

Results: Among diet- and culture-related factors, smoking and hookah use, physical inactivity, nighttime employment, and being single and cultural factors related to breast cancer were selected. Also, based on the proposed model, factors such as comparing the results of previous and current mammograms, the duration of taking contraceptive pills, hysterectomy, hormone replacement therapy, nipple retraction and pain, type of discharge, and detecting a mass in mammograms were effective in detecting the disease. No significant relationship was found between breast cancer and factors such as using the microwave in the kitchen, or the type of rice or oil consumed.

Conclusion: Using dietary habits and cultural factors in the prediction of breast cancer, the proposed model has the least error rate and the most accuracy compared with other models such as fuzzy and neural networks.

Keywords: Genetic Bee Colony Algorithm, Feature Selection, Breast Cancer, Dietary Habits, Cultural Factors, Laboratory Results 


\title{
بهبود الكوريتم زنبور عسل زنتيكى براى انتخاب ويزگىهاى موثر در پيشبينى سرطان پِتان از بين عادات غذايی، عوامل فرهنكى، علايم بالينى و نتايج آزمايشكاهى
}

\author{
مهدى نوشيار : : كروه كامبيوتر، دانشعاه محقق اردبيلى، اردبيل، ايران

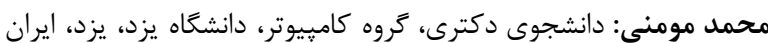

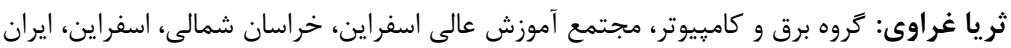

\section{جكيده}

مقدمه: كشف ويزگى هاى موثر در بروز سرطان پستان داراى اهميت است. وجود علايم مختلف اين بيمارى، تشخيص را براى يزشكان

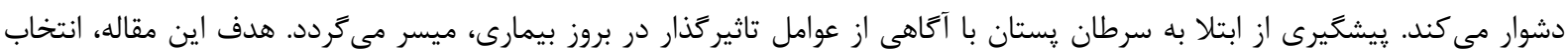

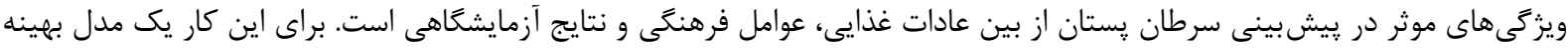

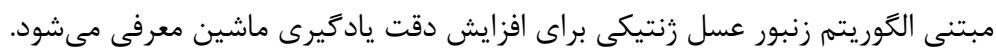

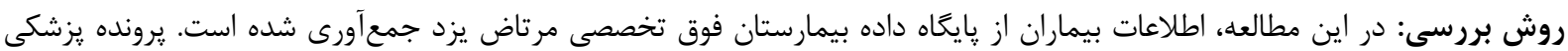

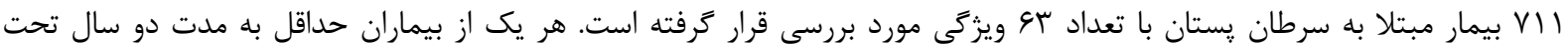

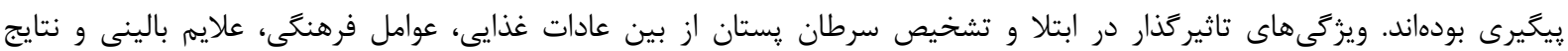

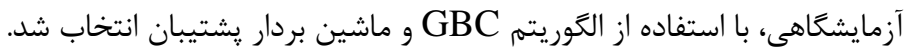

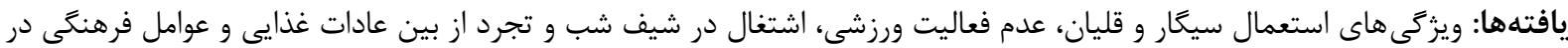

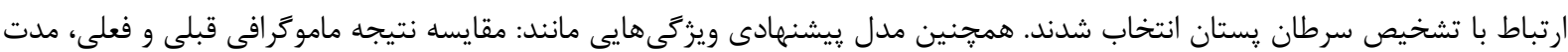

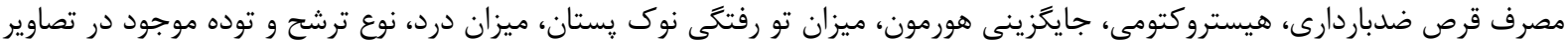

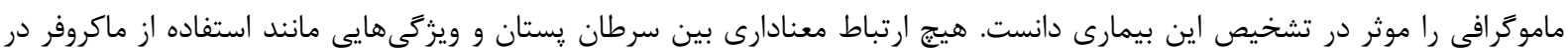
آشيز خانه، نوع برنج و روغن مصرفى يافت نشد.

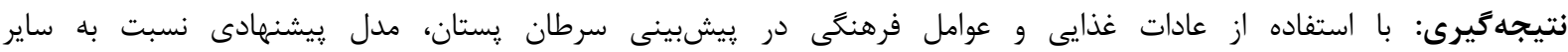
مدل هاى مورد مقايسه مانند فازى و شبكه عصبى، داراى حداقل ميزان خطا و بيشترئ ندين دقت و صحت است.

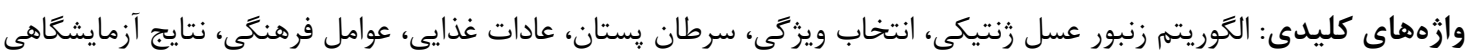




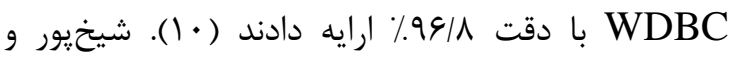

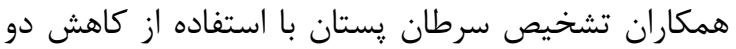

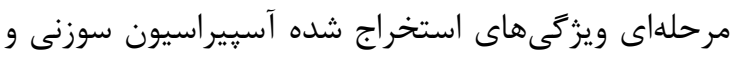
الكوريتمهاى دادهاوى را معرفى كردند (1) (1).

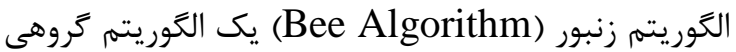
مبتنى بر جستجو است كه در سال هـ • + ميلادى ابداع

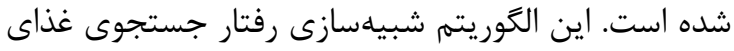
كروههاى زنبور عسل است. در نسخه ابتدايى اين الكوريتم،

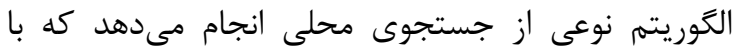

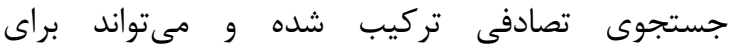
بهينهسازى تركيبى يا بهينهسازى تابعى استفاده شود. اين

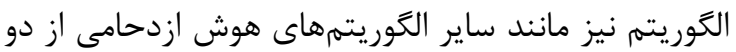
روش اكتشاف و استخراج استفاده مى كند. زنبورهاى كاركر وظيفه استخراج و زنبورهاى ناظر وظيفه اكتشاف را به اله اله

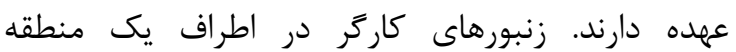
(كَلهاى ييدا شده يا منطقهاى كه شامل جواب مسئله

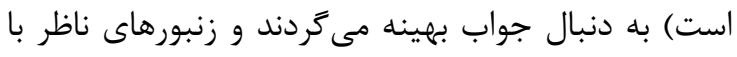
رفتار تصادفى به دنبال ييدا كردن مناطق جديد هستند. استفاده از سه تكنيك دادهاوى براى تشخيص سرطان يستان توسط دلن و همكاران معرفى شد كه بيشبينى

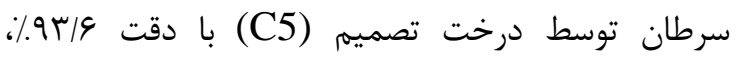
SVM

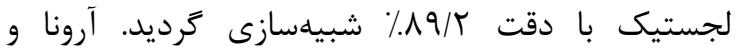

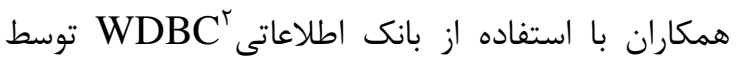
مدلهاى دادهكاوى از قبيل درخت تصميم و بيز ساده و استفادي SVM به ترتيب با دقت

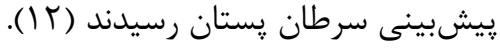

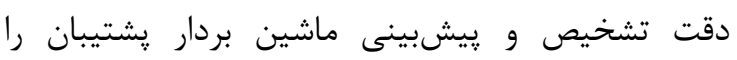
مىتوان از طريق تنظيم يارامترهاى ورودى با استفاده از الكوريتمهاى هوش جمعى افزايش داد. هوش جمعى در در إنى

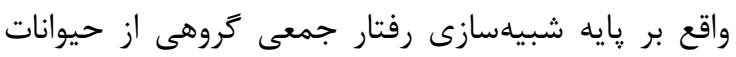

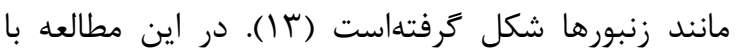
طراحى :رسشنامه، تكميل و گردآورى مجموعه دادهاى

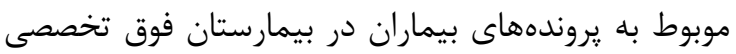
مرتاض يزد، مدلى براى افزايش دقت تشخيص و وِيشبينى برنى ماشين بردار يشتيبان مبتنى بر الكوريتم كلونى زنبور عسل معرفى مى كردد.

${ }^{2}$ Wisconsin Diagnostic Breast Cancer
رشد خارج از قاعده سلولهاى غيرطبيعى در يستان از علل

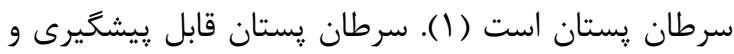

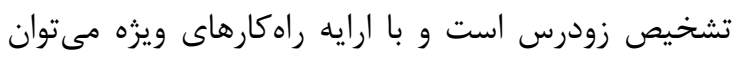
مراجعه ديرهنگام بيمار را كاهش داد. درمان موثر سرطان

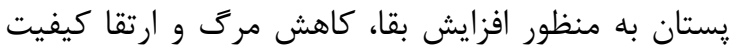

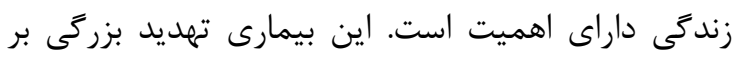

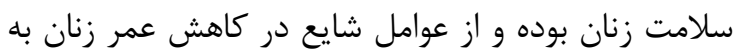

شمار مىرود (r).

براى پِيشبينى، تشخيص و درمان اين بيمارى عوامل

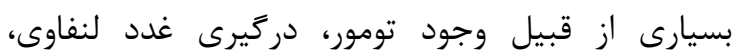
تورفتگى نوك يستان و بروز ترشح در يستان استفاده مىشود (r). وجود شباهت زياد در علايم بالينى و

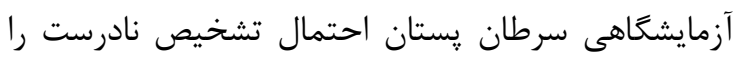
افزايش مىدهد (Y). توده، شايعترين علامت سرطان يستان مى باشد كه در اغلب موارد توسط خود بيمار بصورت اتفاقى كشف مى شود و در بقيه موارد توسط يزشك در معاينه بالينى مشخص مى شود. اين توده ممكن است دردناك باشد؛ ولى در اغلب موارد بدون درد است. در درد بعضى موارد سرطان يستان بلصورت تودههاى متعدد بروز

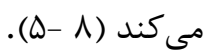
تشخيص و بيشبينى انواع بيمارىها با استفاده از ماشين

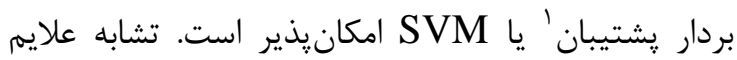

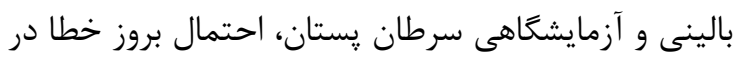
تشخيص را افزايش مىدهد. كشف الكَوهاى مفيد بين بيمارى و علايم بالينى و آزمايشخاهى بيمار از كاربردهاى دهاى

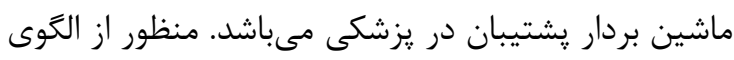

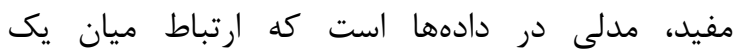
زيرمجموعه از دادههاى بيمار و تشخيص بيمارى را بيان

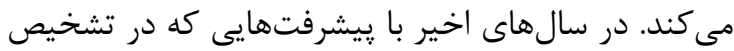

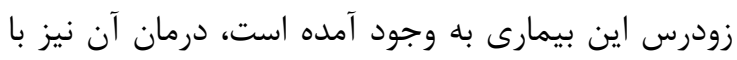
موفقيت بيشترى همراه شده است. اگر تودههاى يستان در اندازه كوجى كشف شوند به خوبى قابل درمان هستند.

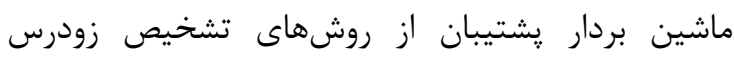
سرطان پستان است (9). استر و همكاران روش تجزيه و تحليل گسسته خطى در الدان

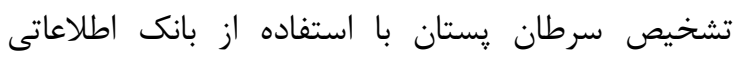

\footnotetext{
${ }^{1}$ Support vector machines
} 
ماموكرافى، علايم بالينى و نتايج آزمايشعاهى نظر خود را اعلام مىنمايد. در تشخيص سرطان يستان يافتههاى

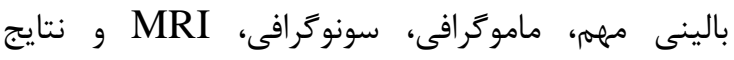

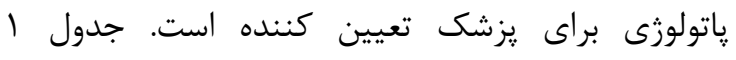

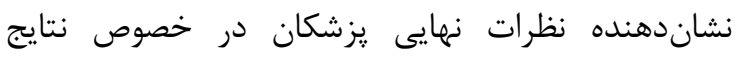

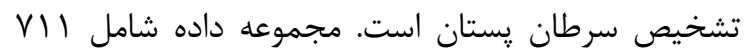
نمونه و بو ويزگى مى باشد.

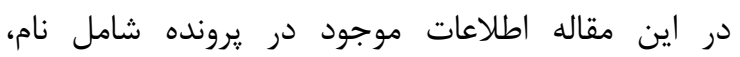
نامخانوادگى، شماره يرونده بيمار و نشانى حذف شدات شداند.

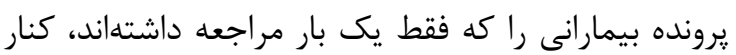

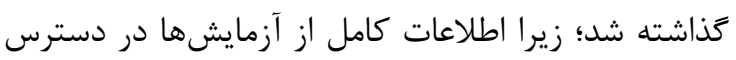

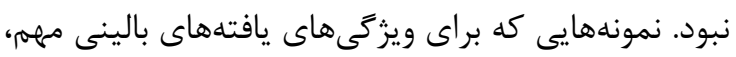

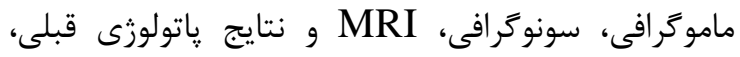

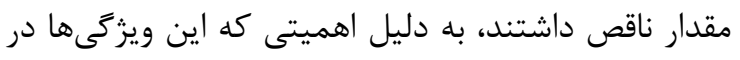

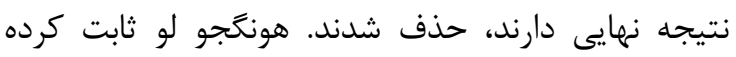
است كه حذف عاقلانه، بهتر از جايكزين كردن ويزگكىهاى

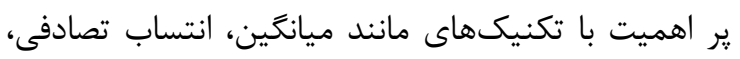

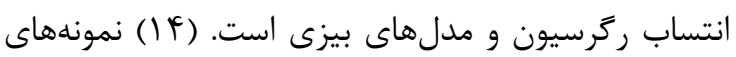
كه داراى קند ويزگى مفقوده بودند نيز حذف كرديدند. قد و وزن نيز به تنهايى اهميتى ندارند، بلكه شاخص توده

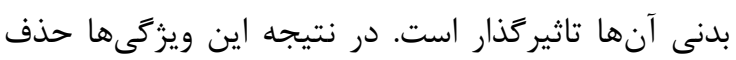
شدند و بهجاى آنها از شاخصهاى مرتبط استفاده شده

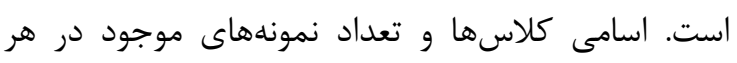
كلاس در جدول r نشان دادهده است.

\begin{tabular}{|c|c|}
\hline امى و تعداد نمونههاى كلاسها & جدول r: \\
\hline تعداد نمونههاى موجود در كلاس & 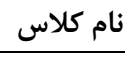 \\
\hline$\Delta \Delta Y$ & سالم \\
\hline זrו & خوش خيم \\
\hline rq & بدخيم \\
\hline
\end{tabular}

ماشينهاى بردار يشتيبان: اساس ماشينهاى بردار

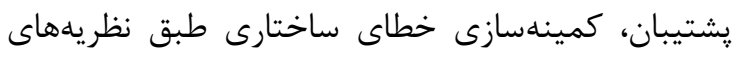

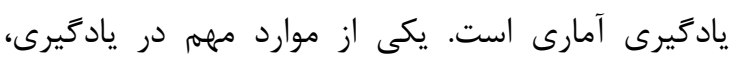

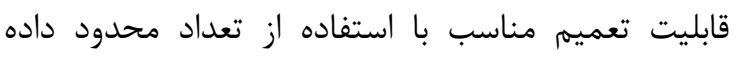

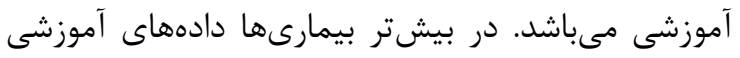

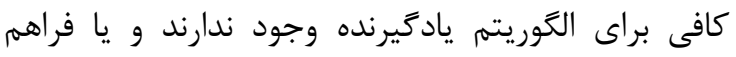

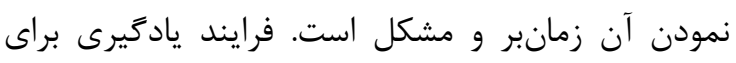

\section{مواد و روشها}

انتظار مراجعهنندكان در مطب ماموگرافيست جهت

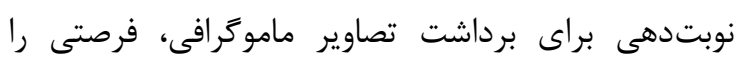

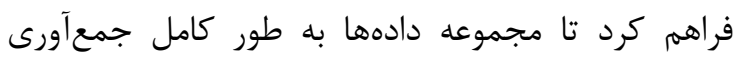
كردد. تكميل بانك اطلاعاتى با اخذ رضايتنامه از يزشك،

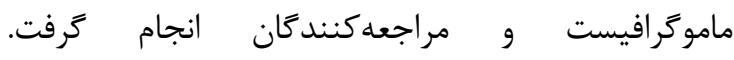

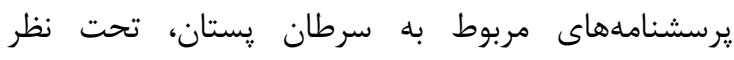

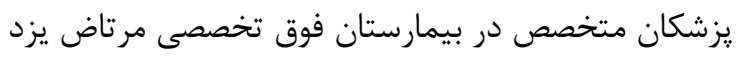

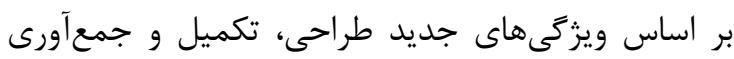

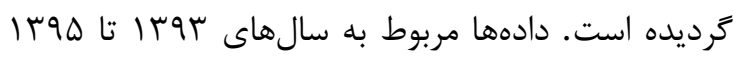

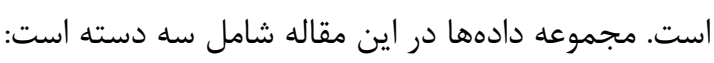

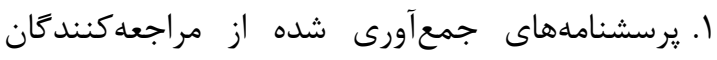

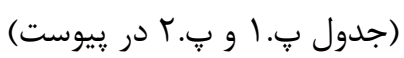

r. فرمهاى تكميلشده توسط تكنسين و ماموكرافيست در بوست

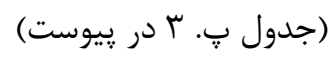

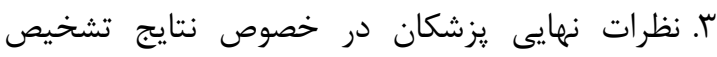

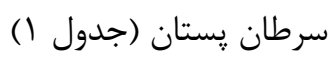

\begin{tabular}{|c|c|}
\hline \multicolumn{2}{|c|}{ سرطان يستان } \\
\hline نظر يزشك & يافته هاى مهم \\
\hline شرح نكات مهمم يافتههاى بالينى & يافته هاى بالينى مههم \\
\hline نتايج بررسى تصوير ماموَرافى & يافته هاى ماموكرافى \\
\hline نتايج بررسى تصوير سونوكرافى & يافته هاى سونوكرافى \\
\hline نتايج بررسى تصوير MRI & يافته هاى MRI \\
\hline شرح مقايسه پاتولوزى قبلى و فعلى & نتايج ياتولوزى قبلى \\
\hline
\end{tabular}

جدول ا: فرم نظرات يزشك معالج در خصوص تشخيص

اطلاعات يرسشنامههاى عادات غذايى از مراجعهكنندگان

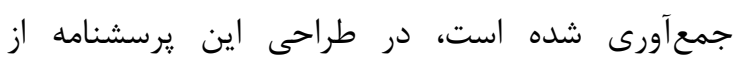
ويزگى هاى جديد مانند استفاده از ماكروفر در آشيز آشخانه،

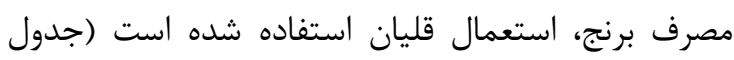

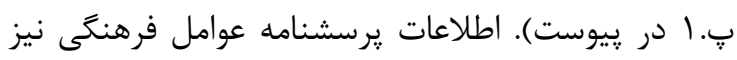

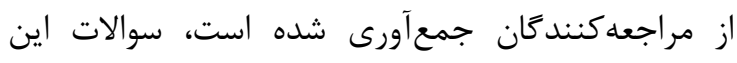

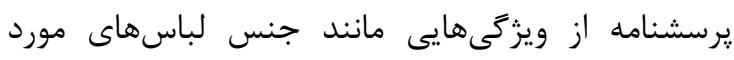

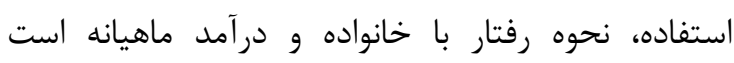

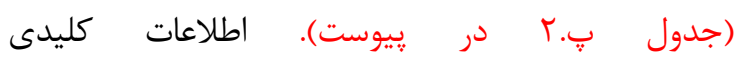
مراجعهكندكان توسط تكنسين و ماموكرافيست تكميل

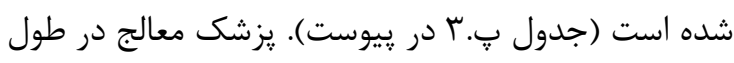

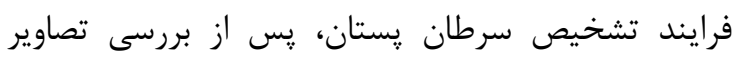


جوابهاى ايجاد شده رتبهبندى مىشوند و ديگر زنبورها

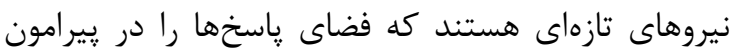
خود براى يافتن بالاترين رتبه محلها جستجو مى كنند كه

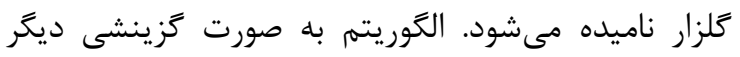
كلزارها را براى يافتن نقطهى بيشينه تابع شايستكى نامئى جستجو مى كند. در نهايت، به منظور دستيابى به يك تعادل بين

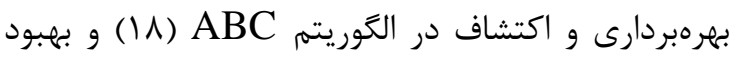

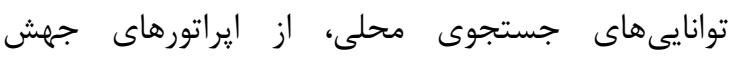

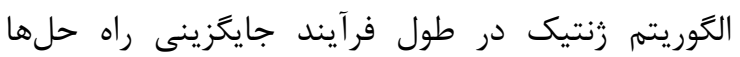

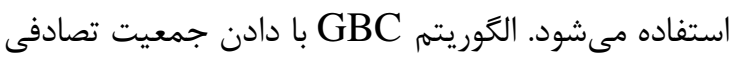
اوليه از فضاى جستجو يعنى ويزگىهاى استخراج شده $\mathrm{X}_{\mathrm{mi}}=\mathrm{X}_{\mathrm{i}}^{\mathrm{min}}+\operatorname{rand} *\left(\mathrm{X}_{\mathrm{i}}^{\max }-\mathrm{X}_{\mathrm{i}}^{\mathrm{min})}\right.$ شروع مىشود:

كه در رابطه بالا X يك بردار راهحل براى مساله بهينهسازى و m=1,..,S, بيان كر تعداد جمعيت اوليه و هر ئ بردار است. سيس تابع برازش هر راه حل محاسبه مى شعود. $\mathrm{P}_{\mathrm{m}}=\frac{\text { Fit }_{\mathrm{m}}\left(\mathrm{x}_{\mathrm{m})}\right.}{\sum_{\mathrm{m}=1}^{\mathrm{sn}} \text { fit }_{\mathrm{m}}\left(\mathrm{x}_{\mathrm{m})}\right.}$

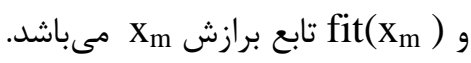

\section{مدل ثيشنههادى} پيشيردازش: در روش پِيشنهادى، علاوه بر انتخاب ويزگى هاى موثر در يِيشبينى سرطان يستان، وزن هر يك

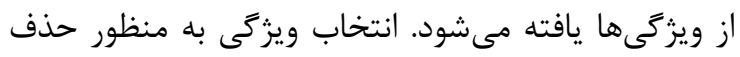

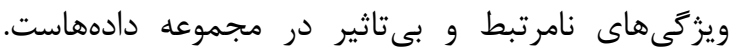

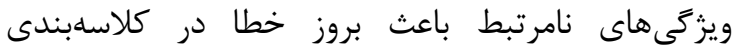

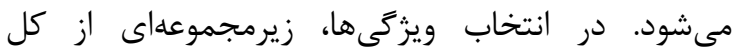

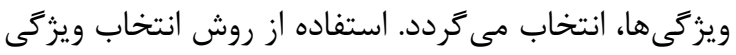
باعث كاهش زمان آموزش، كاهش زمان محاسباتى و ودابـ

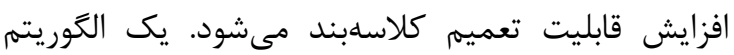
انتخاب ويزگى از يك روش جستجو براى انتخاب زيرمجموعهاى از ويزگى ها و يكى معيار ارزيابى براى

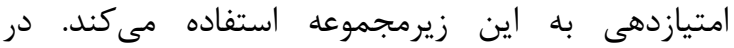

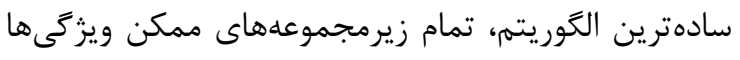

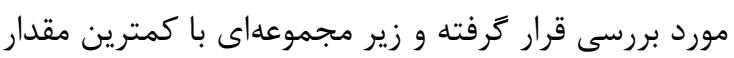

ييشبينى بيمارىها با تعداد محدود داده آموزشى از طريق ماشينهاى بردار رشتيبان امكانيذير است (ه (1).

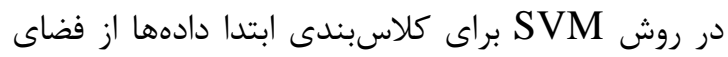

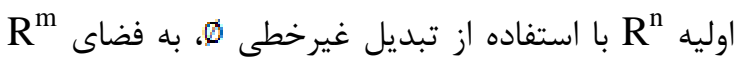

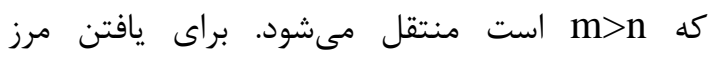
تصميم گيرى بهينه از رابطه زير استفاده مى كردد: $\max _{a v_{\text {.an }}}=\frac{-1}{2} \sum_{i=1}^{n} \sum_{j=1}^{n} a i$ aj yi $y j\left((\emptyset(\mathrm{xi}) . \emptyset(\mathrm{xj}))+\sum_{i=1}^{n} a i\right.$ $0 \leq \mathrm{ai} \leq \mathrm{C} \quad \mathrm{i}=1, \ldots, \mathrm{N}$

$\sum_{\mathrm{i}=1}^{\mathrm{N}}$ ai $\mathrm{yi}=\mathrm{O}$

كه X نقطهاى روى مرز تصميم

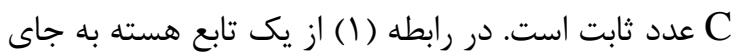
$K(x i, x j)=\varnothing(x i) \varnothing(x j)$ Ф بهصورت زير استفاده مى

با تعيين مقدار

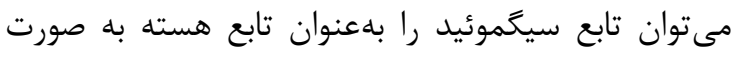
$\left.K\left(x_{i}, X_{j}\right)=\left.e^{\left(-\because \mid x-x_{i}\right.}\right|^{2}\right)$

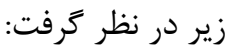
انتخاب مناسب يارامترهاى C و ¥ در الكوريته ماشين

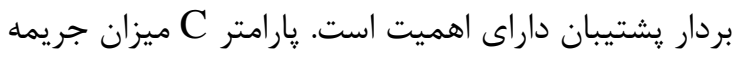

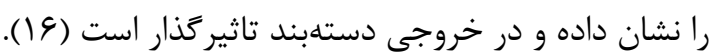

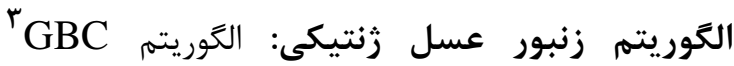

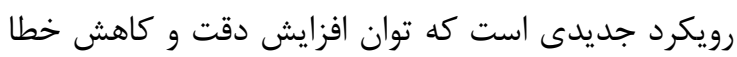

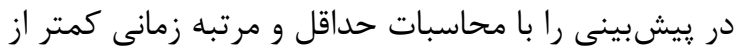
كارهاى مشابه دارد (IV). روال بهينهيابى در الخَوريتم براساس يك روند تصادفى- هدايت شده استوار

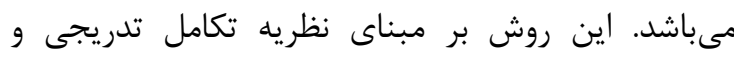

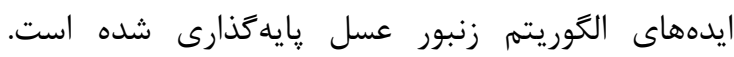
الكوريتم زنبور عسل هر نقطه را در فضاى ڤارامترى

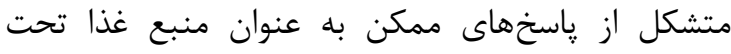

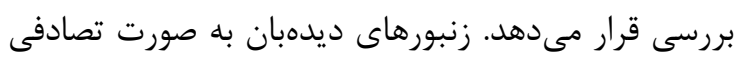

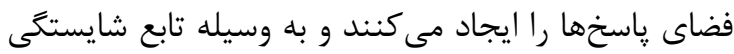
كيفيت موقعيتهاى بازديد شده را كزارش مى بـدهند.

\footnotetext{
${ }^{3}$ Genetic Bee Colony
} 
مرحله زنبورعسل ناظر: در اين مطالعه، عمليات همبرى براى به اشتراك كذارى اطلاعات بين زنبورهاى عسل كاركر و ناظر در فضاى جستجو بهينهسازى (كندو) استفاده مى بـ شود. زنبورهاى ناظر با تماشاى رقص زنبورهاى عسل

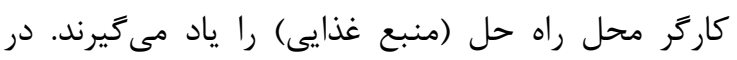

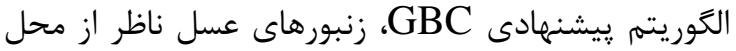
بهترين منبع غذايى، كه راه حلى با بالاترين مقدار

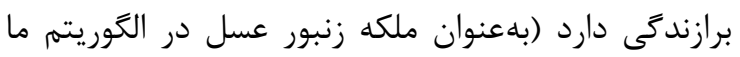
مشخص شدهاند) استفاده مى كنند. شايان ذكر است كه در الكوريتم ABC اصلى، زنبورهاى ناظر از اين اطلاعات

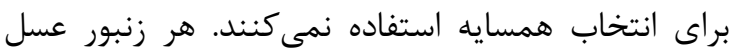

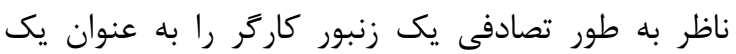
همسايه انتخاب مى كند. در الكوريتم GBC، يك مدل بنول مبتنى بر عمليات همبرى يكسان براى انتخاب همسايه

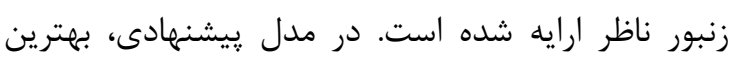

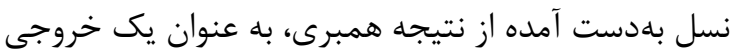

در نظر كرفته مى شود (شكل ().

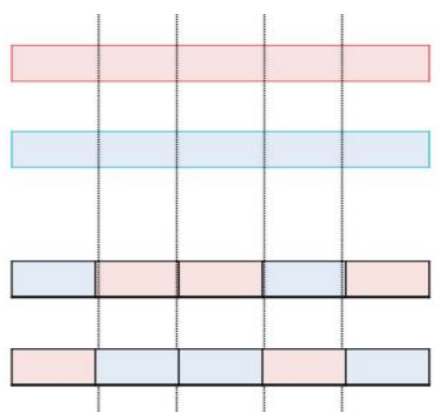

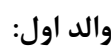

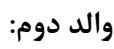

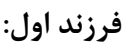

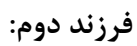

\section{شكل ا : همبرى يكنواخت}

مرحله زنبور ديدهبان: به منظور دستيابى به تعادل بين

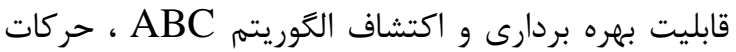
زنبور عسل ديدهبان را در الكَوريتم ABC اصلى اصلاح

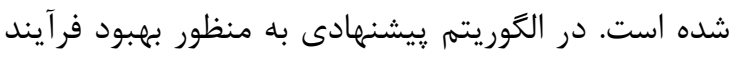

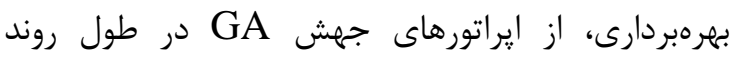
جايكزينى راه حلهاى قديمى استفاده شده است.

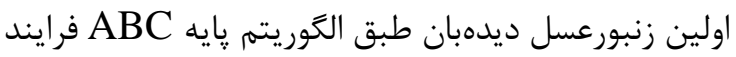

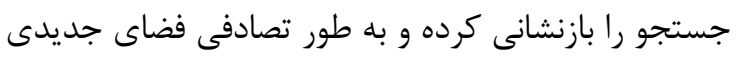

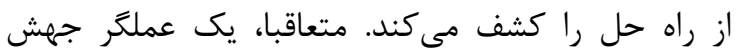

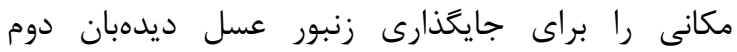

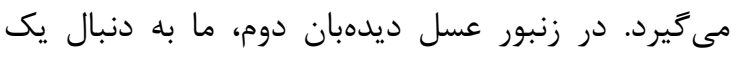

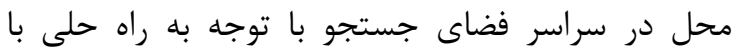

نرخ خطاى كلاسهبند انتخاب مىشود. جستجوى كامل فضاى ويزگى ها داراى بار محاسباتى بالايى است. در اين

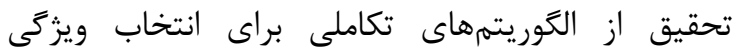

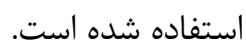
در روش ييشنهادى براى مشخص كردن ارزش و نقش هر يك از ويزگگىها در تشخيص بيمارى به طور تصادفى براى برى

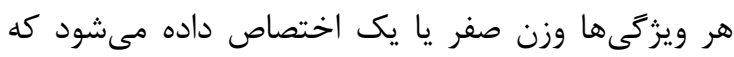
نشاندهنده انتخاب يا عدم انتخاب ويزگ ونى است. مقادير وزندار ويزگى ها به عنوان ورودى به التهاب الثوريتههاى

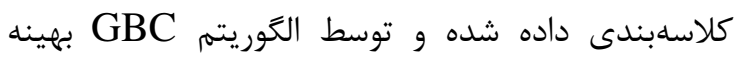
مى مردد. هر راهحل در جمعيت اوليه در الخوريتم

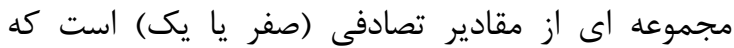
بيان كر وزن هريك از ويزگى مئباشد.

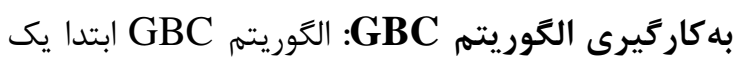

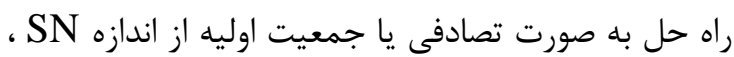

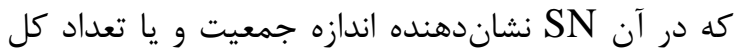

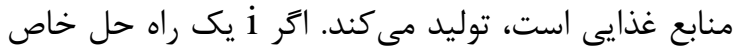

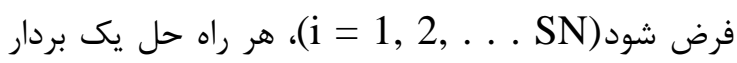

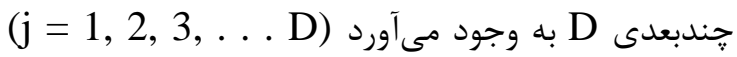

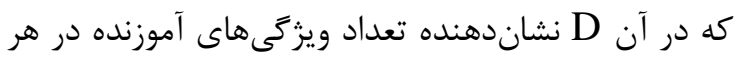

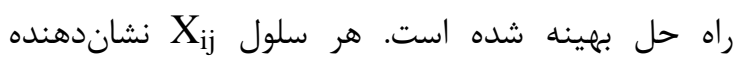

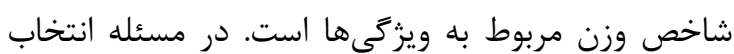
ويزگى، هر راهحل همراه با دقت طبقهبندى كه با استفاده

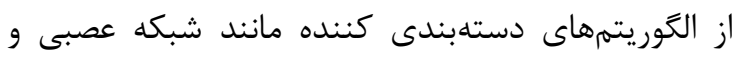

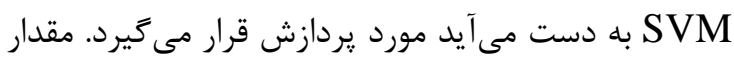
شهد در يك منبع غذايى به مقدار دقت از راه حل وابسته

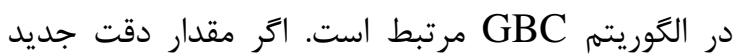

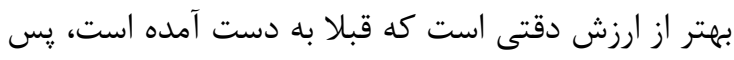

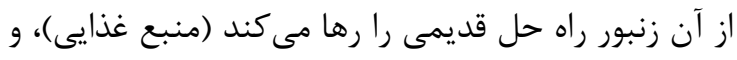
به سوى يكى از راه حلهاى جديد حركت مى كند. درغير آدئ

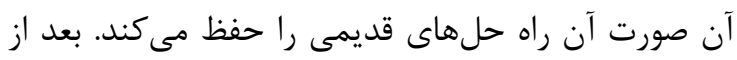

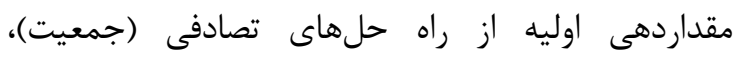

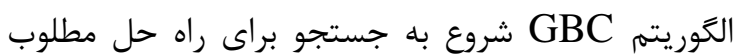

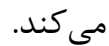

مرحله زنبورعسل كاركر: در اين مرحله، زئل زنبور عسل

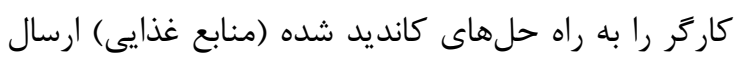

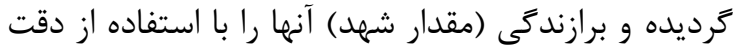

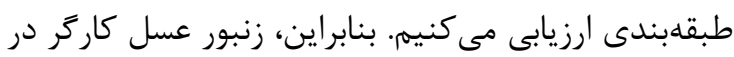
سراسر فضاى راهحل ها جستجو مى كند. 
انجام مىشود. هر زنبور كه كلاسهبندى را با خطاى קيشبينى كمترى انجام دهد، شايستهتر خواهد بودي تخمين خطا بر مبناى نمونه كيرى به روش Cross Validation accuracy است. تابع برازندگى نشاندهنده شايستگى يا توانايى هر

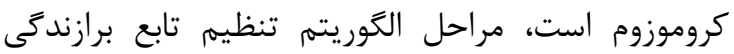
روش يُشنهادى به شرح زير مىباشد.

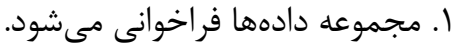

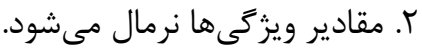

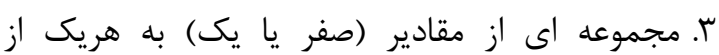
ويزگى ها اختصاص داده مىشود.

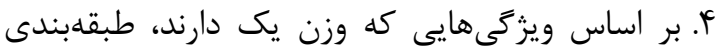

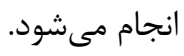
ه. ميزان خطاى طبقلبند محاسبه مىشود.

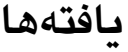

نتايج شبيهسازى نهايى با انتخاب ويزگى هاى مربوط به

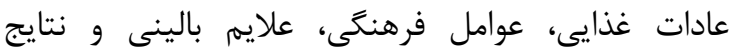

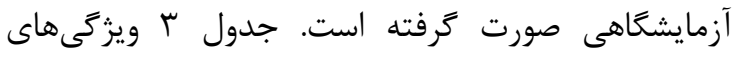
انتخاب شده و حذف شده از عادات غذايى ران راندان مىدهد. همان گَنه كه مشاهده مىشود، مصرف دخانيات

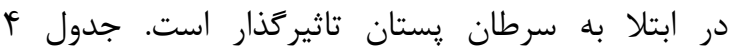

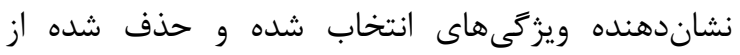

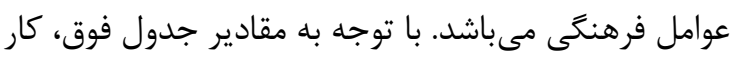
مداوم در شيفت شب ارتباط معنادار با سرطان يستان داشته است. جدول ها ه مهمترين اطلاعات در زمينه

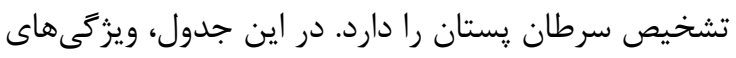
مربوط به فرم تكميلشده توسط تكنسين و ماموكرافيست نشان داده شده است. مقايسه تصاوير ماموكرافى قبلى با

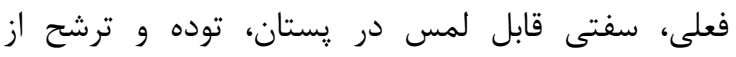

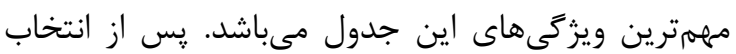

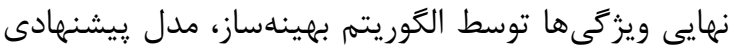

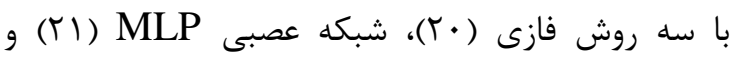

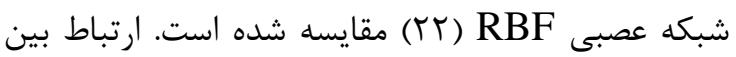
كلاسهاى واقعى و كلاسهاى پيشبينى شده با استفاده از

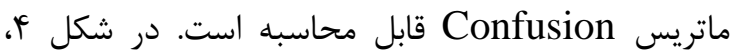

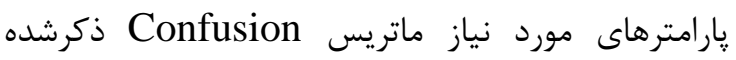
است. براى مقايسه مدل ييشنهادى با ساير روشها از إز
بالاترين برازندگى كه تاكنون توليد شده است هستيم. نرخ احتمال جهش 1• • • تنظيم شده است (شكل ؟). ساختار روش پيشنهادى در شكل ץ نشان داده شده است.
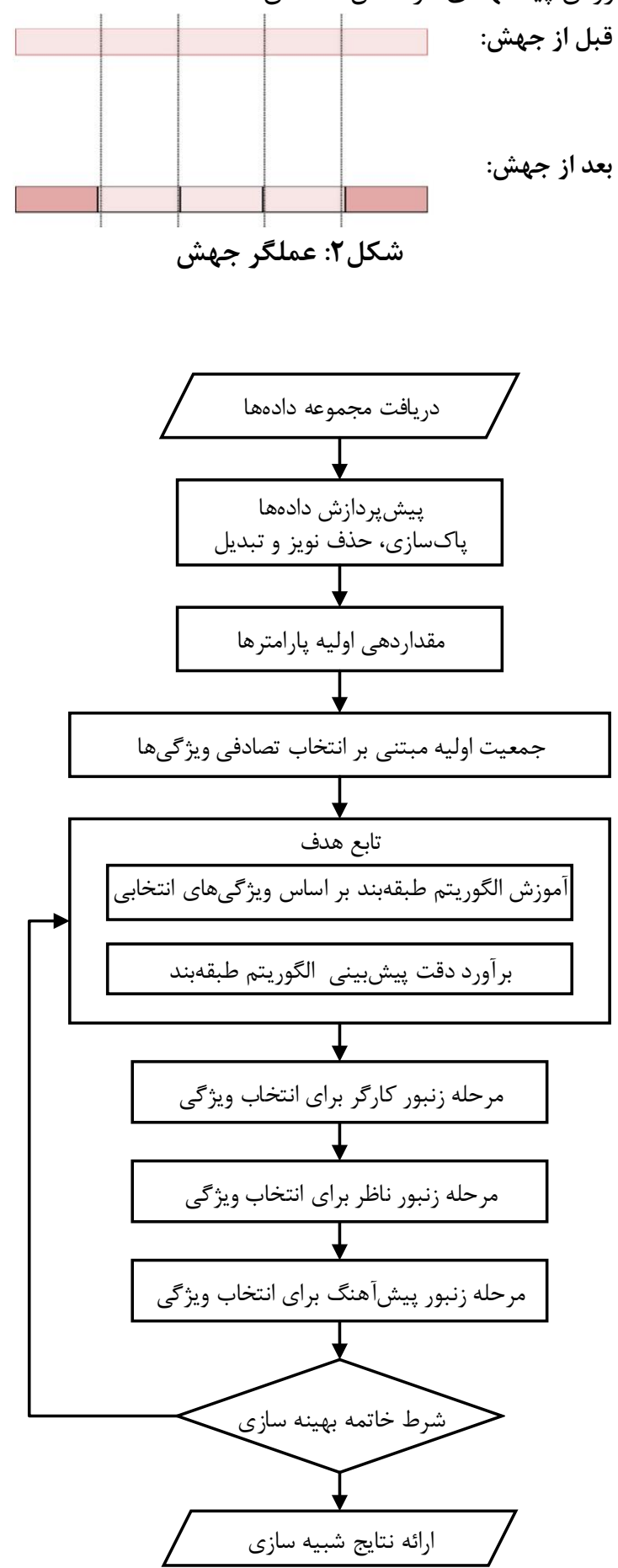

شكل r: ساختار روش بِيشنهادى

קيادهازى روش بيشنهادى: عمل كلاسهبندى با مقادير ويزگى هاى انتخاب شده، كه بر اساس هريك از زنبورها محاسبه مى 
مقايسه نشاندهنده برترى عملكرد مدل ييشنهادى مى -

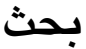

مدل بيشنهادى با معرفى روشى جهت يِيشبينى سرطان

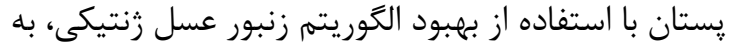

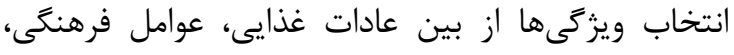

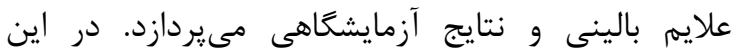

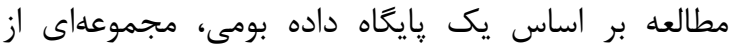
الكوهاى كمتر شناخته شده و موثر در بروز سرطان يستان

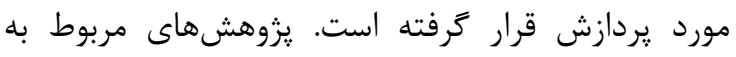
ييشبينى سرطان يستان محدوديتهايى از قبيل تعداد

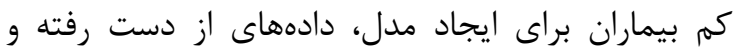
متغيرهاى ناقص را دارا مىباشند. در اين يزوهش تعداد إداد إداد

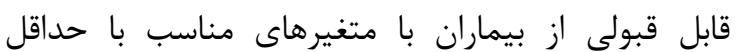
داده هاى از دست رفته به كار گرفته شده است. ويزگ

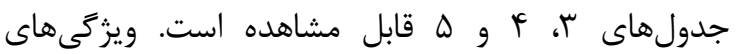
منتخب در ارتباط با تشخيص سرطان يستان از بين عادات

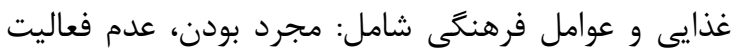

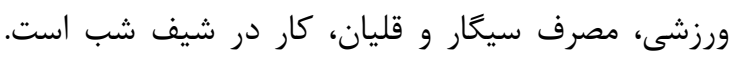
همجنين مقايسه نتيجه ماموكرافى قبلى و فعلى، مدت في مصرف قرص ضد باردارى، هيستروكتومى، جايكزينى

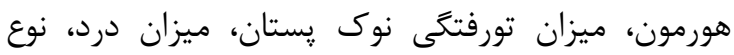

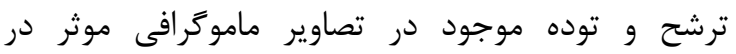
تشخيص سرطان يستان شناخته شد. هيجّونه رابطه

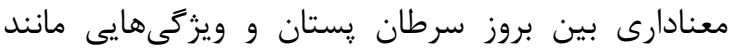

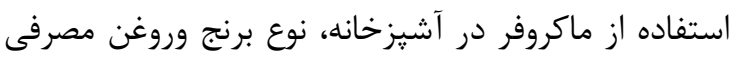
ييدا نشده است. آتشى و همكاران تعداد . .. رابطه انجمنى با ضرايب

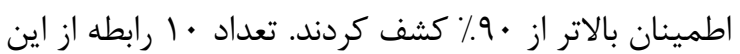

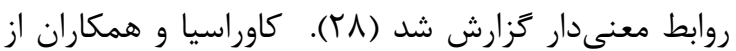
درخت تصميم جهت يِيشبينى سرطان يستان با دقت (Yץ

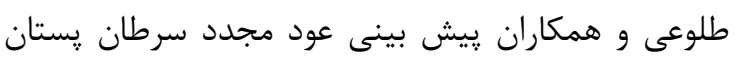
به كمك سه تكنيك داده كاوى را ارايه دادند (• آمان. بررسىهاى صورت كرفته نشان مىدهد كه دقت در سه الكوريتم داده كاوى، يعنى درخت تصميم كَيرى،

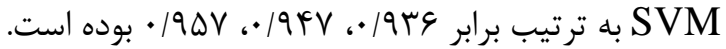

معيارهاى Specificity ، Accuracy ، I F-Measure grecision

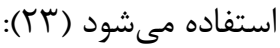

جدول ا: معيارهاى مقايسه مدل بيشنههادى با ساير

روشها

Accuracy $=(\mathrm{TP}+\mathrm{TN}) /$ All

Sensitivity $=\mathrm{TP} /(\mathrm{TP}+\mathrm{FN})$

Specificity $=\mathrm{TN} /(\mathrm{FP}+\mathrm{TN})$

Precision $=\mathrm{TP} /(\mathrm{TP}+\mathrm{FP})$

Recall $=\mathrm{TP} /(\mathrm{TP}+\mathrm{FN})$

F Measure $=2 *$ Precision $*$ Recall

Precision + Recall

:TP: تعداد ركوردهايى كه به درستى، مثبت تشخيص داده

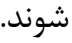
شوند :TN تعداد ركوردهايى كه به درستى، منفى تشخيص داده

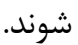
:FP تعداد ركوردهايى كه به غلط، مثبت تشخيص داده : FP

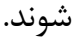
FN تعداد ركوردهايى كه به غلط، منفى تشخيص داده - FN

شكل fا، مقايسه درصد خطا براى پِيشبينى سرطان يستان بين الخوريتهمهاى (Y)

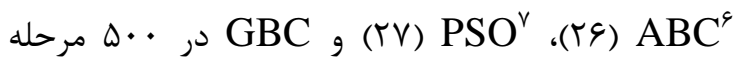
نشان داده شده است. همان طور كه مشاهده مىشود، دقت

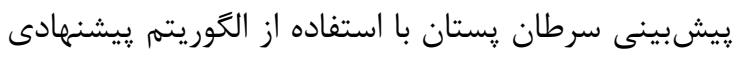

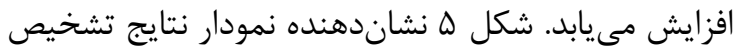

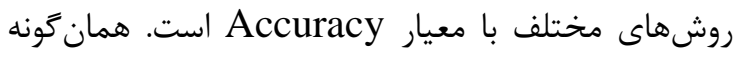

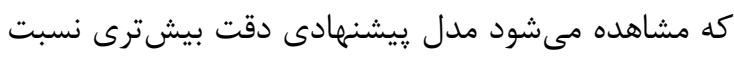

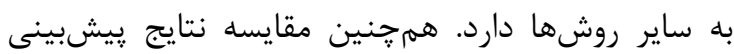

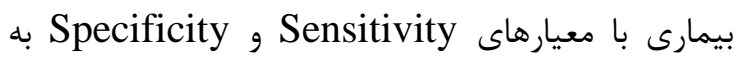
ترتيب در جدولهاى \& و V نمايش داده شدهاست. جدول

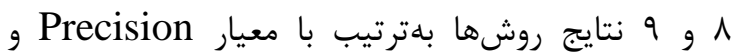
F-Measure مورد مقايسه قرار كرفته است. نتايج

\footnotetext{
${ }^{4}$ Genetic algorithm

${ }^{5}$ Ant colony optimization

${ }^{6}$ Artificial bee colony

${ }^{7}$ Particle swarm optimization
} 
جدول بّ: ويزَى هاى انتخاب شده و حذف شده از عادات غذايى جهت پيشبينى سرطان

حذف ويزگى ها در فرايند بهينهسازى

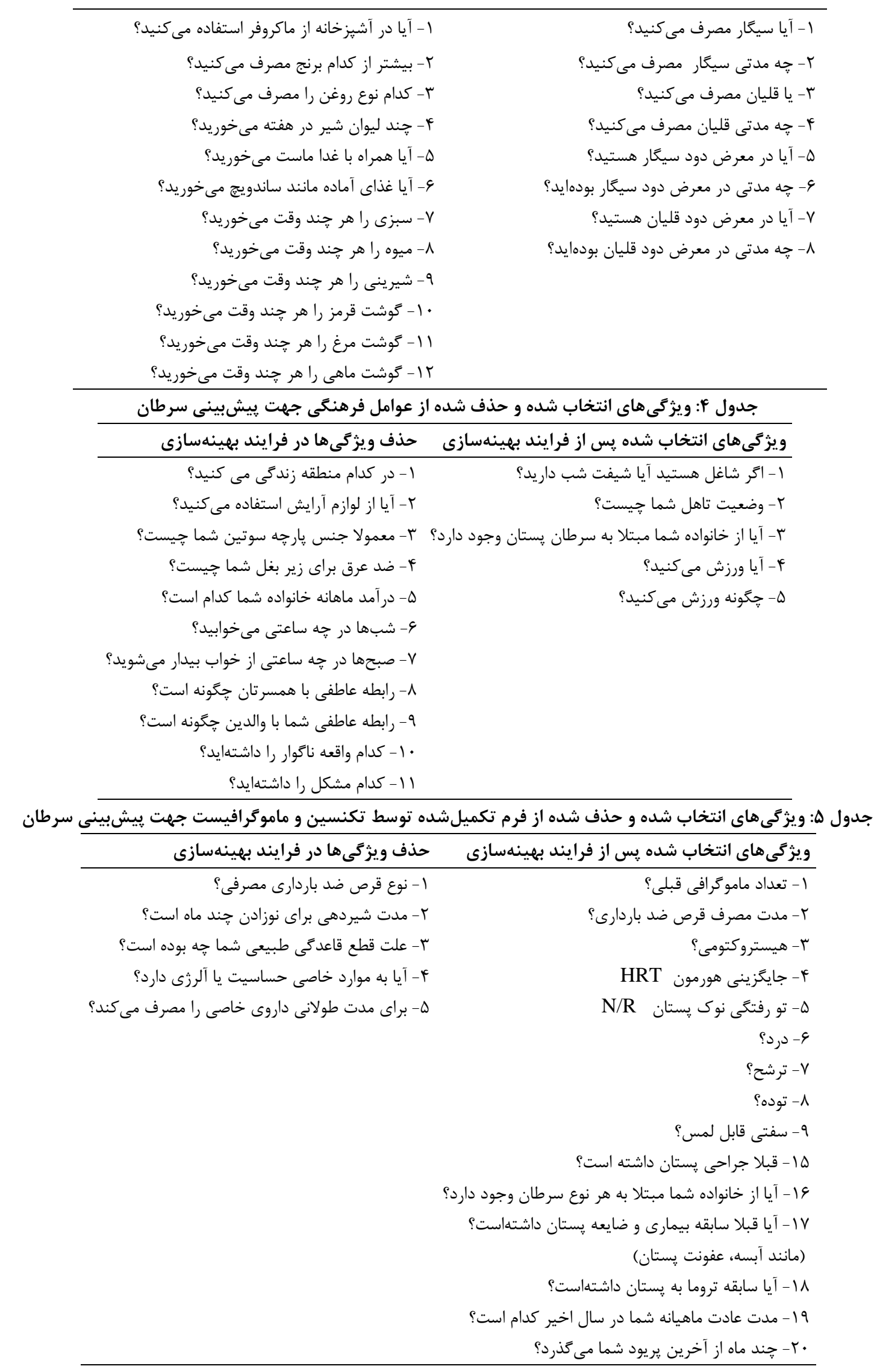

ويثَّى هاى انتخاب شده يس از فرايند بهينهسازى 
داده بيماران بومى مبتلا به سرطان رِّتان بيمارستان

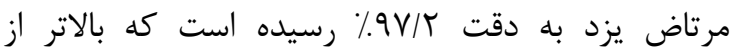
تحقيقات مشابه بر روى مجموعه دادهاى متفاوت بوده

\section{نتيجهكيرى}

جستجو در پايعاه دادههاى يزشكى براى رسيدن به دانش

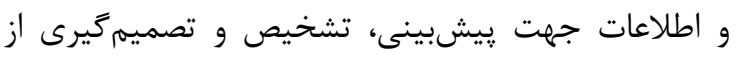

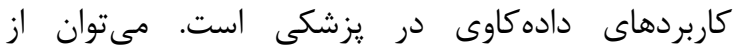

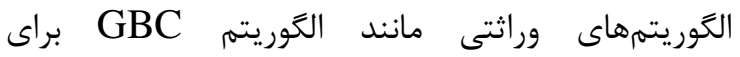

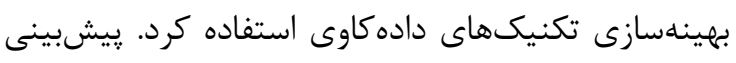

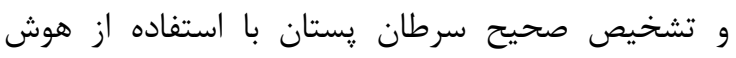

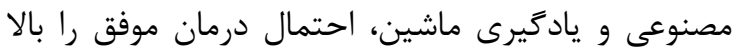

روش يِيشنهادى با بهبود الكوريتم زنبور عسل زنتيكى به انتخاب ويزگ هاى موثر در پيشبينى سرطان يستان از

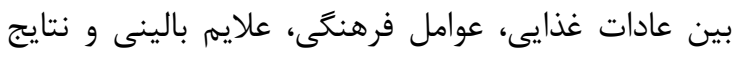

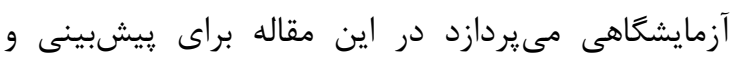

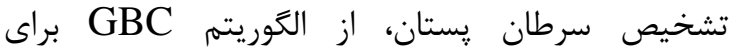
بهينهسازى نتايج ماشين بردار ريشتيبان استفاده شد و يك إنى

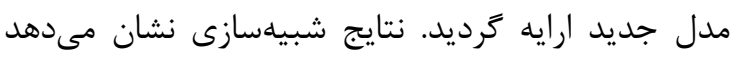

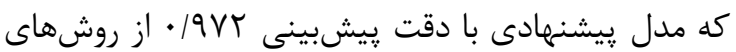

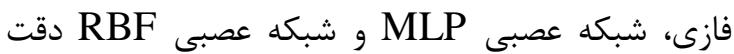
بيشترى دارد. كار در شيفت شب، وضعيت تاهل، سابقه

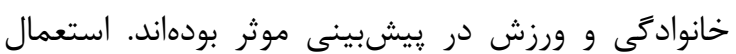

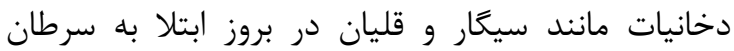
״ستان موثر بوده است. تعداد ماموكرافى قبلى، مدت

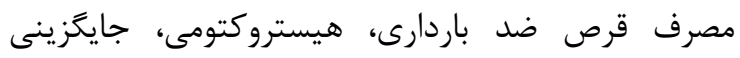
هورمون HRT، تو رفتگى نوك يستان N/R، درد، ترشح، توده، سفتى قابل لمس در يُّتان، سابقه خانوادگى در تشخيص سرطان يستان تاثير داشتهاند.

\section{تقدير و تشكر}

نويسندًان بر خود لازم مىدانند از مديريت محترم

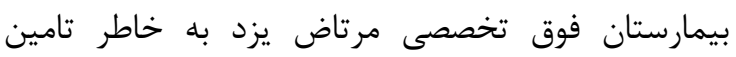
مجموعه دادههاى مورد نياز جهت انجام اين يزوهش تشكر بران

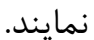

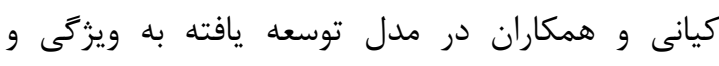
حساسيت به ترتيب 90\% و 9 9 \% رسيدند. در اين مطالعه

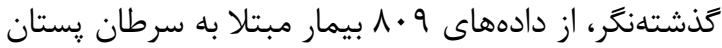

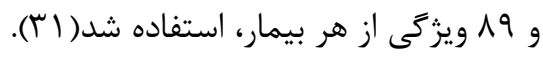

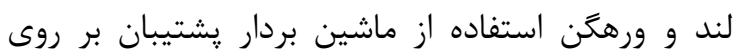
مجموعه دادههاى سرطان يستان براى ييشبينى استفاده

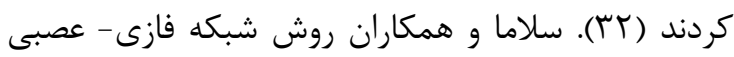

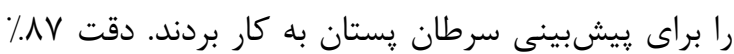

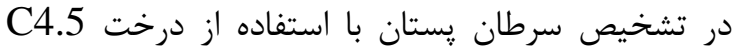

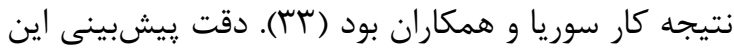

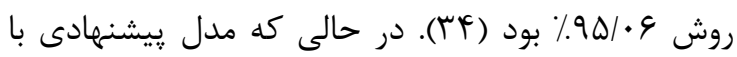

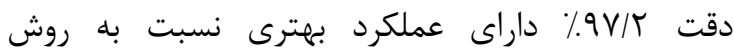

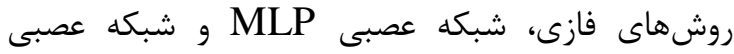
RBF در تشخيص سرطان پِّتان است. جاراسيا و همكاران با استفاده از روش SVM به به دقان

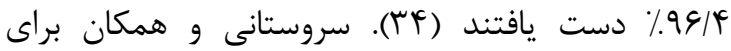
يِيشبينى درجه بدخيمى سرطان يستان به مقايسه

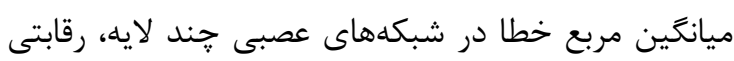

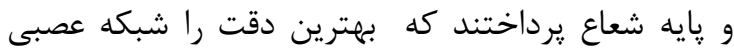

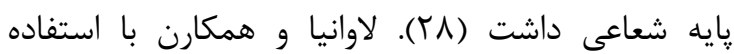

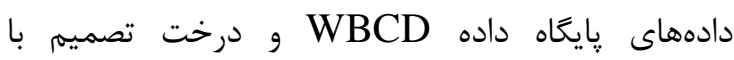

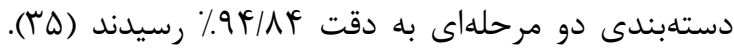

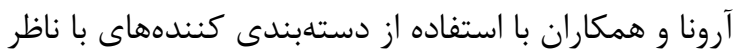
مانند روش نايو بيز و درخت تصميم برروى مجموعها

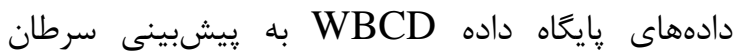
يستان يرداختند. بر اساس معيارهاى Accuracy، Recall ،Precision ،Specificity ،Sensitivity F-Measure ور نتايج شبيهسازى، مدل يِيشنهادى نتايج بهترى نسبت به اين مقاله دارد (ع)). نتايج

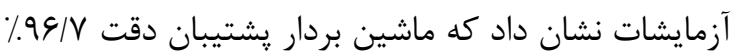

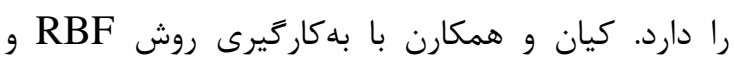
براى پيشبينى سرطان پِتان به ترتيب به دقت

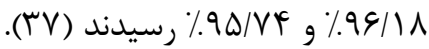

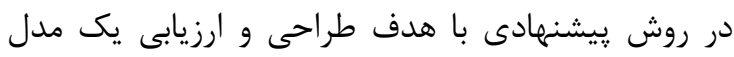

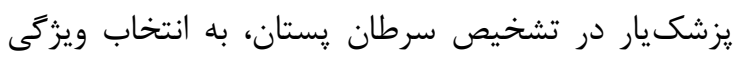

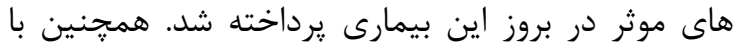

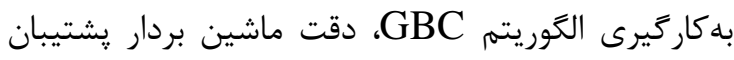

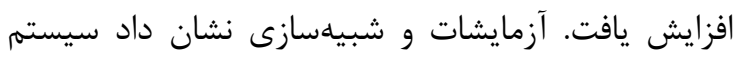
يزشكيار معرفى شده در اين يزوهش بر روى مجموعه 


$$
\begin{aligned}
& \text { نويسندكان اعلام مىدارند كه هينج تعارض منافعى در } \\
& \text { ئزوهش حاضر وجود ندارد. }
\end{aligned}
$$

\section{References}

1. Nakai K, Xia W,Liao H, et al. The role of PRMT1 in EGFR methylation and signaling in MDA-MB-468 triple-negative breast cancer cells. Breast Cancer. 2018; 25(1): 7480.

2. Rheinbay E, Parasuraman P,Grimsby J, et al. Recurrent and functional regulatory mutations in breast cancer. Nature 2017; 547(7661): 55-60.

3. Inoue $M$, Nakagomi $H$, Nakada $H$, et al. Specific sites of metastases in invasive lobular carcinoma: a retrospective cohort study of metastatic breast cancer. Breast Cancer 2017; 24(5): 667-72.

4. Quist J,Mirza H, Chon U cheang M, et al. Association of a four-gene decision tree signature with response to platinum-based chemotherapy in patients with triple negative breast cancer. Clinical oncology 2017; 1006.

5. Quail D F,C.olson o,Bhardwaj P, et al. Obesity alters the lung myeloid cell landscape to enhance breast cancer metastasis through IL5 and GM-CSF. Nature cell biology 2017; 19(8): 974.

6. Denkert C, Liedtke C, Tutt A, et al. Molecular alterations in triple-negative breast cancer- the road to new treatment strategies. The Lancet 2017; 389(10087): 2430-42.

7. Tomioka N, Azuma M, Ikarashi M, et al. The therapeutic candidate for immune checkpoint inhibitors elucidated by the status of tumor-infiltrating lymphocytes (TILs) and programmed death ligand 1 (PD-L1) expression in triple negative breast cancer (TNBC). Breast Cancer. 2018; 25(1): 34-42.

8. Heitz A E, Baumgartner R, Baumgartner K, et al. Healthy lifestyle impact on breast cancer-specific and all- cause mortality. Breast cancer research and treatment. 2018; 167(1): 171-81.

9. Howlader $\mathrm{N}$, cronin $\mathrm{K}$, Kurian $\mathrm{A}$, et al. Differences in Breast Cancer Survival by Molecular Subtypes in the United States.
Cancer Epidemiology and Prevention Biomarkers 2018; 27(6):619-26.

10. Ster B, Dobnikar A. Neural networks in medical diagnosis: Comparison with other methods. Proc Int Conf Eng Appl neural networks 2016; 427-30.

11. Sheikhpour R, Sarram M, Zare Mirakabad $\mathrm{M}$, et al. Breast Cancer Detection Using Two-Step Reduction of Features Extracted from Fine Needle Aspirate and Data Mining Algorithms. Iranian Quarterly Journal of Breast Disease 2015; 7(4).

12. Delen D, Walker G, Kadam A. Predicting breast cancer survivability: a comparison of three data mining methods. Artificial Intelligence in Medicine 2005; 34(2): 11327.

13. Mohd Zamani M, Musirin I, Suliman S, et al. Multi-area economic dispatch performance using swarm intelligence technique considering voltage stability. International Journal on Advanced Science. Engineering and Information Technology 2017; 7(1): 1-7.

14. Lu H, Rudy S, Liu H. Neurorule: A connectionist approach to data mining. arXiv preprint arXiv. 2017; 1701 (01358).

15. Saed S. Support Vector Machine. Support Vector Machines. Np, nd Web 262017.

16. Gu B, S. Sheng V. A robust regularization path algorithm for \$ \$nu \$-support vector classification. IEEE Transactions on neural networks and learning systems 2017; 28(5): 1241-8.

17. Alshamlan MH, Ghada HB, A. Alohali Y. Genetic Bee Colony (GBC) algorithm: A new gene selection method for microarray cancer classification. Computational biology and chemistry $2015 ; 56: 49-60$.

18. Hancer E, Xue B, Zhang M, et al. Pareto front feature selection based on artificial bee colony optimization. Information Sciences 2018; 422: 462-79. 
19. Rohani A, Taki, Abdollahpour M. A novel soft computing model (Gaussian process regression with K-fold cross validation) for daily and monthly solar radiation forecasting (Part: I). Renewable Energy 2018; 115: 411-22.

20. Taneja Sh, Suri B, Gupta S, et al. A Fuzzy Logic Based Approach for Data Classification. Data Engineering and Intelligent Computing. Springer, Singapore 2018; 605-16.

21. Hramov AE, Forolov NS, Maksimenko VA, et al. Artificial neural network detects human uncertainty. Chaos: An Interdisciplinary Journal of Nonlinear Science 2018; 28(3): 033607.

22. Agrawal Sh, Agrawal j, Kaur Sh, et al. A comparative study of fuzzy PSO and fuzzy SVD- based RBF neural network for multilabel classification. Neural Computing and Applications 2018; 29(1): 245-56.

23. Prahlad A, Parag G, Rajiv K, et al. Data mining systems and methods for heterogeneous data sources. U.S. Patent No. 2018; 9: 738-910.

24. Kadri R, F. Boctor F. An efficient genetic algorithm to solve the resource-constrained project scheduling problem with transfer times: The single mode case. European Journal of Operational Research 2018; 265(2): 454-62.

25. Mellal M, Williams E J. A survey on ant colony optimization, particle swarm optimization, and cuckoo algorithms. Handbook of research on emergent applications of optimization algorithms. IGI Globa. 2018; 37-51.

26. Karaboga De, Basturk B. A powerful and efficient algorithm for numerical function optimization: artificial bee colony (ABC) algorithm. Journal of global optimization.2007; 39(3): 459-71.

27. Kenned J. Particle swarm optimization. Encyclopedia of machine learning. Springer US 2011; 760-6.

28. Atashi A, Kiani B. Discover hidden patterns in the actual data set of patients with breast cancer using the data mining technique. Journal of Informatics. Health and Biomedicine 1394; 8 (1): 60-5.

29. Chaurasia S, Chakrabarti P. An Approach with Support Vector Machine using Variable Features Selection on Breast Cancer Prognosis. International Journal of Advanced Research in Artificial Intelligence 2013; 2(9): 38-42.

30. Toloei Ashlaghi A, Pour Abrahamid A, Ebrahimi M, at al. Prediction of recurrence of breast cancer using three data mining techniques. Journal of Breast Diseases of Iran 2012; 5 (4): 34-23.

31. Kiani B, Atashi A. Create a data mining prognostic model to predict the recurrence of breast cancer. Journal of Informatics. Health and Biomedical Sciences 1393; 1(1): 26-31.

32. Land WH, Verheggen EA. Multiclass Primal Support Vector Machines For Breast Density Classification. Int J Comput Biol Drug Des 2009; 2(1):21-57.

33. Salama GI, Abdelhalim M, Zeid M. Breast cancer diagnosis on three different datasets using multi-classifiers. Breast Cancer (WDBC) 2012; 190-6.

34. Chaurasia S, Chakrabarti P. An Approach with Support Vector Machine using Variable Features Selection on Breast Cancer Prognosis. International Journal of Advanced Research in Artificial Intelligence 2013; 2(9): 38-42.

35. Lavanya D, Rani KU. Ensemble decision tree classifier for breast cancer data. International Journal of Information Technology Convergence and Services 2012; 2(1): 17-24.

36. Aruna S, Rajagopalan DS, Nandakishore LV. Knowledge based analysis of various statistical tools in detecting breast cancer. Computer Science \& Information Technology 2011; 2: 37-45.

37. Kiyan T, Yildirim T. Breast cancer diagnosis using statistical neural networks. IU-Journal of Electrical \& Electronics Engineering 2011; 4(2): 1149-53. 